\title{
The Cultural Master Plan of Bamiyan: The Sustainability Dilemma of Protection and Progress
}

\author{
Michael Jansen and Georgios Toubekis
}

\begin{abstract}
Beyond the Buddha Cliff, the World Heritage property of Bamiyan consists of several archaeological areas embedded into an extraordinary cultural landscape not adequately defined at the time of the nomination. Therefore, the Cultural Master Plan was envisioned as guidance for the development of a rural environment under cultural preservation objectives. The plan introduces a zoning scheme defining land use regulations for the protection of cultural areas and proposing designated areas for urban development. Lack of adequate legal protection, too rigid enforcement of land use restrictions on the local level, and the aspirations of the people for a rapid change of their living conditions resulted in increasing uncertainties on the validity of the plan. It is argued that a monitoring steering group composed of international and national experts, and local stakeholders, are helpful to counterbalance uncoordinated international aid assistance and inefficient governmental supervision that resulted in development strategies overemphasizing urbanization approaches in conflict with the rural character of the valley. The authors propose to reconsider urbanization within the Bamiyan Valley and to reconcile the objectives of urban and rural development inspired by a sustainable development vision as proclaimed with the Sustainable Development Goals (SDGs) of the UN 2030 Agenda for Sustainable Development.
\end{abstract}

Published jointly by the United Nations Educational, Scientific and Cultural Organization (UNESCO), 7, place de Fontenoy, 75007 Paris, France, the UNESCO Office in Kabul, ICON Compound, Supreme Road, Off Jalalabad Road, PD 9, Kabul, Afghanistan, and Springer Nature Switzerland AG, Gewerbestrasse 1, 6330 Cham, Switzerland.

\footnotetext{
M. Jansen

Aachen Center for Documentation and Conservation, RWTH Aachen University, Aachen, Germany

German University of Technology - GUtech, Muscat, Oman

Research Centre Indian Ocean - RIO at GUtech, Muscat, Oman e-mail: michael.jansen@rio-heritage.org

G. Toubekis ( $\square)$

Aachen Center for Documentation and Conservation, RWTH Aachen University, Aachen, Germany

Research Centre Indian Ocean - RIO at GUtech, Muscat, Oman e-mail: toubekis@dbis.rwth-aachen.de
} 
Keywords Remote sensing $\cdot$ Word heritage $\cdot$ Management $\cdot$ Sustainable development $\cdot$ Monitoring

\section{Introduction}

Since their creation, the Buddha figures of Bamiyan always have been an object of fascination for people of many different faiths who experienced in this landscape a deep sense of purity of peace regardless from which part of the world they arrived in this remote valley in the mountains of the Hindu-Kush. Though repeatedly intentionally damaged in the course of time the total destruction of the Bamiyan Buddha figures in March 2001 will stand forever in the history of Afghanistan as an era of violent rule of religious extremism fueled with barbaric actions and atrocities, of which the country was freed of more than 15 years ago.

The Government of Afghanistan has proclaimed on several occasions its commitment to contribute to the ideals set out in the World Heritage Convention of 1972 and especially to conceive its cultural policy as an incubator for an authentic Culture of Peace to overcome the effects of decades of war and military conflict within the country.

The debate on the future of the historical monuments in Bamiyan connects directly to the notion of peace as a specific condition that Bamiyan has retained despite unstable and hostile circumstances all over the country in recent years. The future of the site where once the most abundant depictions of Buddha stood is therefore inseparable from the future of the valley as a whole. The debate on the possibility of the reconstruction of the Buddha figures, therefore, is one aspect of a broader view of preservation that encompasses the entire cultural landscape of the valley, of which the niches and the fragments of the destroyed Buddha figures are a significant part. The efforts of preserving the authentic spirit of the place need to be embedded in the theme of broader landscape protection and evolving the entire Bamiyan Valley into a livable place for the generations to come (Fig. 1).

The Cultural Master Plan has been envisioned as guidance on how to consider preservation objectives within a broader range of development aspects. This vision includes infrastructure and economic and social development aspects, and it is assumed by the authors that the World Heritage property has the inherent potential to efficiently contribute to these overall development objectives and to provide collective benefit for the entire society of Bamiyan and Afghanistan as a whole. This approach calls for a conservation and management strategy that aligns with an overall broader development policy, and that does not compromise, but in contrast, support the Outstanding Universal Value (OUV) of the property in line with the recent UNESCO Policy for the integration of sustainable development perspectives into the processes of the World Heritage Convention.

It is the plea toward the international community to support the Government of Afghanistan in its endeavor of promoting the values of Bamiyan for tourism and 


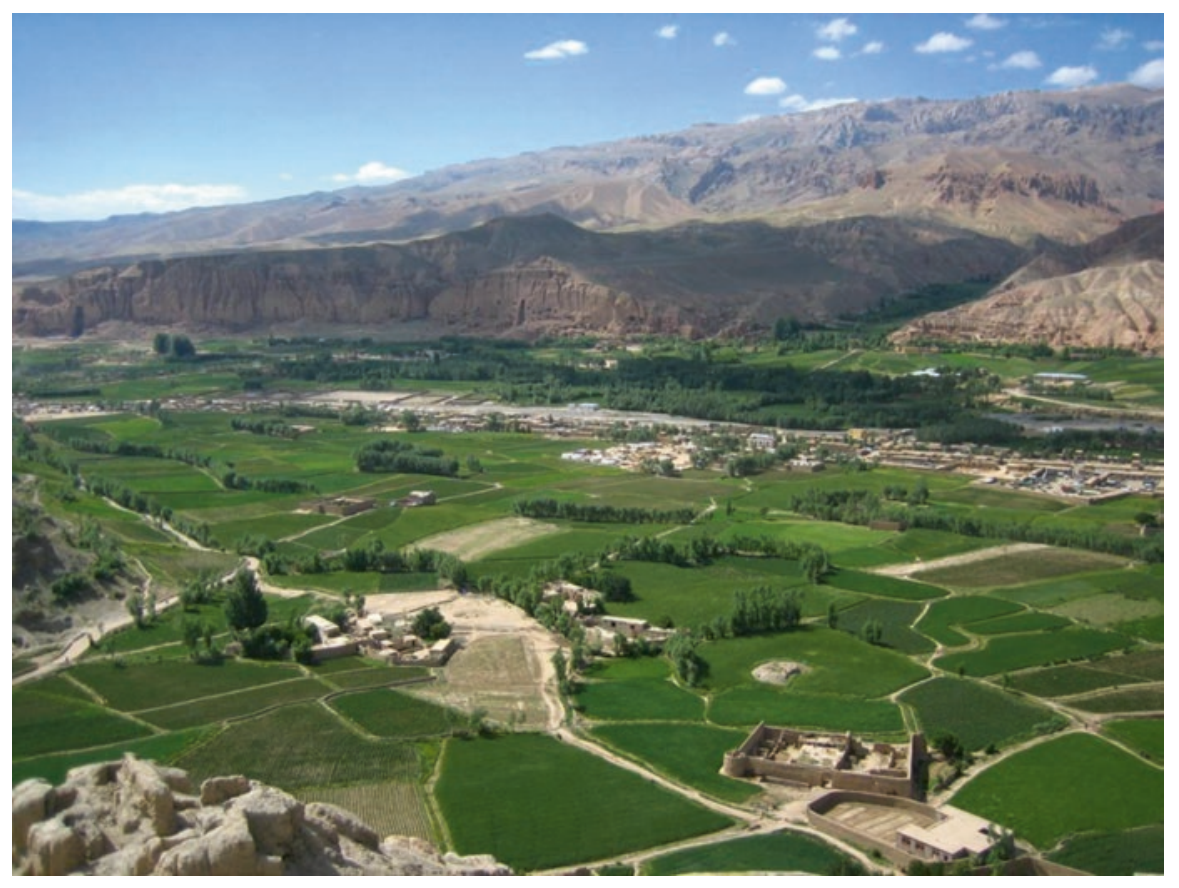

Fig. 1 Cultural landscape of the Bamiyan Valley with the main cliff in the background and the modern bazaar along the river in 2004. (ㅇ G.Toubekis)

other cultural purposes, which as a result will foster peace and security, probably the highest value for this war-torn country.

Following the introductory remarks, the second section explains the evolution of the Cultural Master Plan. In the third section, the zoning concept of the Cultural Master Plan is described in detail, and the following fourth section will point out the conflict lines that arise from aspiration of development and the efforts for the preservation of the cultural landscape. The fifth section will conclude with a proposal of how to harmonize planning activities in the Bamiyan Valley inspired by a sustainable development vision for the future of the Bamiyan province as a whole as proclaimed with the Sustainable Development Goals (SDGs) of the UN 2030 Agenda for Sustainable Development.

\section{The Evolution of the Cultural Master Plan (CMP) also Named "Protective Zoning Plan"}

Shortly after a UNESCO international seminar held in Kabul in May 2002 as a forerunner of the International Coordination Committee (ICC) in July 2002, a joint UNESCO/ICOMOS mission visited Bamiyan headed by Prof. Michael Petzet, in 
those days World President ICOMOS. ${ }^{1}$ As a result of this mission and upon invitation by ICOMOS Germany and funded by the German Government in November 2002, a workshop took place in Munich with high Afghan Government representatives, members of the UNESCO World Heritage Center (Paris), and international experts involved in the safeguarding process of Bamiyan (Bamiyan Expert Working Group BEWG). During this workshop, first steps for the consolidation and preservation of the Buddha niches and wall paintings were discussed. Furthermore, the uncertainty on the extent of the underground archaeological remains was a topic of concern to the representatives of the Afghan Government. It was, therefore, recommended to conduct further archaeological surveys and mappings to understand the extent of the archaeological zone through precise topographic maps indicating the cultural area to be protected (ICOMOS 2002) also in light of pressure from population growth and expected future infrastructure projects in a valley hardly developed so far. ${ }^{2}$

The draft nomination text of Bamiyan for the inscription in the World Heritage List had been supported 2 weeks before the nomination in Durban by the ICC in June 2003 on its first (and only) plenary session in Paris. This text still contained a profound definition on the cultural landscape, reading:

Bamiyan Valley is a landscape $e^{3}$ that has evolved through geological formation and human intervention, and the process of the evolution in form and component features is still visible today. Even today, the landscape is continuously used, and it retains an active social role in local communities. (ICC 2003)

This definition was confirmed in the ICOMOS evaluation of the World Heritage nomination (ICOMOS 2003). However, it was not entirely integrated into the summary of cultural values of the final nomination text.

Under the registration number 208rev, ${ }^{4}$ the Cultural Landscape and Archaeological Remains of the Bamiyan Valley was inscribed on the List of World

\footnotetext{
${ }^{1}$ In addition, the mission consisted of representatives of the Afghan Government, Mr. Ahad Abassi and Mr. Ferozi of the UNESCO, representatives Christian Manhart and Sarah Finke, and ICOMOS members, Prof. Jansen, RWTH Aachen University - Aachen Center for Documentation and Conservation (ACDC, Dipl.-Ing. Mario Santana Quintero, M.Sc. of Conservation, (ACDC), Dr. Jörg Fassbinder, geophysicist, Bavarian State Conservation Office, Dr.-Ing. Zou Yazou, Geoengineer, University of the German Armed Forces, Munich, observer Mr. Paul Bucherer Dietschi, Switzerland (see Government of Afghanistan World Heritage nomination dossier 20 May 2003, appendix E).

${ }^{2}$ See also Government of Afghanistan World Heritage nomination dossier 20 May 2003, appendix F. ${ }^{3}$ This followed the definition of an "organically evolved landscape" according the Cultural Landscape category (ii) as defined in the Annex 3 of the Operational Guidelines to the World Heritage Convention (Fowler 2003, Mitchell et al. 2009). For more information on the UNESCO view on Cultural Landscapes, see http://whc.unesco.org/en/culturallandscape/

${ }^{4}$ The monuments of the Bamiyan Valley were recommended for inscription on the World Heritage List already in 1983 "on the condition that the authorities define a large perimeter of protection which would include the cliffs and the valley, and provide a map indicating the delimitation of this zone" (SC/83/CONF.009/2, p.2), but the World Heritage Committee had deferred the inscription since the conditions were not met at the time ot the meeting (SC/83/CONF.009/8, p.11). The nomination of 2003 with the reference to the Cultural Landscape is thus a revision of this initial nomination intended to fulfil the conditions as stated in 1983.
} 
Heritage at the 27th session of the World Heritage Committee in Durban (July 2003). The site was simultaneously inscribed on the World Heritage List in Danger due to the severe delicate state of conservation of the archaeological remains (especially the stability of the Buddha niches) and the lack of a management system to ensure the integrity of the archaeological remains and the cultural landscape on the long term. While eight archaeological sub-sites were defined within their property and buffer zones, the Cultural Landscape as part of the revised nomination in 2003 had neither been defined in quality nor in quantity (see Table 1).

Table 1 World Heritage property Bamiyan as of 2003 - a serial nomination of eight separated archaeological sub-areas each mentioned with their buffer zone but omitting to indicate the parts of the cultural landscape in which they are situated

\begin{tabular}{|c|c|c|c|c|}
\hline ID & Name and location & Coordinates & $\begin{array}{l}\text { Property } \\
\text { (ha) }\end{array}$ & \begin{tabular}{|l|} 
Buffer \\
zone (ha)
\end{tabular} \\
\hline \multirow[t]{2}{*}{$\begin{array}{l}208- \\
001\end{array}$} & \multirow{2}{*}{$\begin{array}{l}\text { Bamiyan Cliff including niches of the } 38 \text { meter } \\
\text { Buddha, seated Buddhas, } 55 \text { meter Buddha and } \\
\text { surrounding caves }\end{array}$} & $\begin{array}{l}\mathrm{N} 34^{\circ} 50^{\prime} \\
49.00^{\prime \prime}\end{array}$ & \multirow[t]{2}{*}{105} & \multirow[t]{2}{*}{222.25} \\
\hline & & $\begin{array}{l}\text { E } 67^{\circ} 49^{\prime} \\
30.90^{\prime \prime}\end{array}$ & & \\
\hline \multirow[t]{2}{*}{$\begin{array}{l}208- \\
002\end{array}$} & \multirow[t]{2}{*}{$\begin{array}{l}\text { Kakrak Valley caves including the niche of the } \\
\text { standing Buddha }\end{array}$} & $\begin{array}{l}\mathrm{N} 34^{\circ} 48^{\prime} \\
59.60^{\prime \prime}\end{array}$ & \multirow[t]{2}{*}{15} & \multirow[t]{2}{*}{33} \\
\hline & & $\begin{array}{l}\text { E } 67^{\circ} 51^{\prime} \\
4.90^{\prime \prime}\end{array}$ & & \\
\hline \multirow[t]{2}{*}{$\begin{array}{l}208- \\
003\end{array}$} & \multirow[t]{2}{*}{ Qoul-I Akram Caves in the Fuladi Valley } & $\begin{array}{l}\mathrm{N} 34^{\circ} 49^{\prime} \\
25.30^{\prime \prime}\end{array}$ & \multirow[t]{2}{*}{6} & \multirow[t]{4}{*}{40.5} \\
\hline & & $\begin{array}{l}\text { E } 67^{\circ} 47^{\prime} \\
53.70^{\prime \prime}\end{array}$ & & \\
\hline \multirow[t]{2}{*}{$\begin{array}{l}208- \\
004\end{array}$} & \multirow[t]{2}{*}{ Kalai Ghamai Caves in the Fuladi Valley } & $\begin{array}{l}\mathrm{N} 34^{\circ} 49^{\prime} \\
13.60^{\prime \prime}\end{array}$ & \multirow[t]{2}{*}{5.5} & \\
\hline & & $\begin{array}{l}\text { E } 67^{\circ} 47^{\prime} \\
14.50^{\prime \prime}\end{array}$ & & \\
\hline \multirow[t]{2}{*}{$\begin{array}{l}208- \\
005\end{array}$} & \multirow[t]{2}{*}{ Shahr-i-Zuhak } & $\begin{array}{l}\mathrm{N} 34^{\circ} 49^{\prime} \\
34.40^{\prime \prime}\end{array}$ & \multirow[t]{2}{*}{18} & \multirow[t]{2}{*}{13} \\
\hline & & $\begin{array}{l}\text { E } 66^{\circ} 53^{\prime} \\
24.50^{\prime \prime}\end{array}$ & & \\
\hline \multirow[t]{2}{*}{$\begin{array}{l}208- \\
006\end{array}$} & \multirow[t]{2}{*}{ Qallay Kaphari A } & $\begin{array}{l}\mathrm{N} 34^{\circ} 48^{\prime} \\
39.50^{\prime \prime}\end{array}$ & \multirow[t]{2}{*}{0.06} & \multirow[t]{4}{*}{17} \\
\hline & & $\begin{array}{l}\text { E } 66^{\circ} 50^{\prime} \\
36.70^{\prime \prime}\end{array}$ & & \\
\hline \multirow[t]{2}{*}{$\begin{array}{l}208- \\
007\end{array}$} & \multirow[t]{2}{*}{ Qallay Kaphari B } & $\begin{array}{l}\mathrm{N} 34^{\circ} 48^{\prime} \\
46.40^{\prime \prime}\end{array}$ & \multirow[t]{2}{*}{0.06} & \\
\hline & & $\begin{array}{l}\text { E } 66^{\circ} 51^{\prime} \\
0.10^{\prime \prime}\end{array}$ & & \\
\hline \multirow[t]{3}{*}{$\begin{array}{l}208- \\
008\end{array}$} & \multirow[t]{2}{*}{ Shahr-i-Ghulghulah } & $\begin{array}{l}\mathrm{N} 34^{\circ} 49^{\prime} \\
57.60^{\prime \prime}\end{array}$ & \multirow[t]{2}{*}{9.3} & \multirow[t]{2}{*}{13.2} \\
\hline & & $\begin{array}{l}\text { E } 67^{\circ} 50^{\prime} \\
20.80^{\prime \prime}\end{array}$ & & \\
\hline & Total areas & & 159 & 339 \\
\hline
\end{tabular}


With the UNESCO project for the Safeguarding of the Bamiyan Site funded by the Government of Japan soon, a framework was established and is still active for implementing emergency and long-term preservation measures at the site (UNESCO 2003, 2005, 2008, 2012). On its second meeting in 2003 again in Munich, the Bamiyan Experts Working Group (BEWG) recommended that a comprehensive management plan should be prepared by the National Research Institute of Cultural Properties Tokyo (NRICPT). The concept for the management plan was later in 2004 further developed into a regulated zoning system to be adopted for the control of land use and building construction in and around Bamiyan site (JCICC 2004). For putting this idea into reality, close contact with the Governor of Bamiyan and the Ministry of Urban Development could be established. ${ }^{5}$ This cooperation turned out to be extremely fruitful for the development of the Cultural Master Plan (CMP) which was headed and coordinated by RWTH Aachen University, in cooperation with ICOMOS Germany and NRICPT and under the supervision of the Ministry of Information and Culture and the Ministry of Urban Development. In setting up the CMP, not only the cultural property within the defined cultural zone of the valley but also the future residential, urban development, and planning of the valley were included.

The stated vision was to ensure the protection of cultural heritage resources in the face of rapidly increasing infrastructure development and to accommodate the tourism potential and housing needs of the local population. Therefore UNESCO had entrusted RWTH Aachen University to provide technical assistance to the Government of Afghanistan for the development of a master plan. The finalized zoning proposal was presented in December 2005 to the Afghan government and was officially approved in March 2006 by the Ministry of Urban Development. The approval of the master plan has enabled so far the completion of the abovementioned comprehensive site management plan, defining the roles of the relevant authorities for the management and monitoring of the property (UNESCO (2006) - 30COM 7A 23).

The first need was to obtain a mapping at scale 1:5000 - 1:150.000 to understand the broader landscape context and acquire detailed high-resolution documentation of the eight sub-sites and their buffers, as the precise delineation of their boundaries has a direct influence on private property, mostly owned by farmers. As national survey maps at sufficient scale and precision were not available, RWTH Aachen University decided to buy satellite images which guaranteed the latest topography and land details. An area of 45 square kilometers was mapped for the creation of the Cultural Master Plan. In the plan, several national and international experts ${ }^{6}$ researched, recorded, and evaluated the proposal in an interdisciplinary approach (Jansen and Toubekis 2013).

\footnotetext{
${ }^{5}$ Governor of Bamiyan in these days was HE Ms. Habiba Sarabi, the Ministry of Urban Development in those days was headed by HE Minister Pashtun and the Deputy Ministry Djalalzada. The Ministry was renamed later to Ministry of Urban Development Affairs.

${ }^{6}$ The results include the mapping of the vernacular architecture (Lohmann 2005) and a geomporphological analysis of the valley (Reinecke 2005), and are summarized in the Cultural Master Plan Reports as data collection on all relevant findings (see Jansen and Toubekis 2013).
} 
The Cultural Master Plan study is based on the analysis of geomorphological landscape features and of anthropogenic interventions into the landscape of the Bamiyan Valley. The research indicates flooding hazard zones based on catchment analysis and interpretation of land surface features, and it includes a quantitative and qualitative mapping of the main water channels of the central Bamiyan Valley. This water channel-based agriculture together with the historic remains and traditional settlement structures mark the extent of the cultural landscape of the Bamiyan Valley. The Cultural Master Plan includes a precise mapping of these channels and traditional settlement structures. It includes as well an assessment of traditional building techniques and typology of structures and has identified 44 individual historic structures of outstanding cultural significance within the cultural landscape. The CMP consists of a data collection and analysis of these important cultural features of the valley and furthermore a comprehensive set of topographic maps (last updated in 2010). The findings of the CMP study are summarized in a report and have been conceptualized in a zoning proposal indicating favorable land use for protection and management of the cultural landscape through the national and local planning authorities.

\section{The Zoning Concept of the Cultural Master Plan}

As one of the research results, five zonings were defined. The zoning concept of the Cultural Master Plan (CMP) is symbolized by a pyramidal scheme marking the CMP zones 1-4 for the cultural landscape. CMP Zone 5 is not containing elements of CMP zones 1-4 and is demarked separately indicating particular development areas (see Table 2 and Fig. 2).

CMP Zone 1 (World Heritage Protection Zone) represents the eight sub-areas of the World Heritage property (see Table 1) along with their buffers as defined in the 2003 nomination dossier under the jurisdiction of the World Heritage Convention of 1972 and administered by the Ministry of Information and Culture. Zone 1 covers a territory of approx. Five square kilometers including private property.

Table 2 Zoning overview of the cultural master plan

\begin{tabular}{l|l|c}
\hline CMP zone & Name of zone & $\begin{array}{l}\text { Area in } \\
\mathrm{km}^{2}\end{array}$ \\
\hline Zone 1 & World heritage protection zone & 5 \\
\hline Zone 2 & Archaeological heritage protection zone & 6 \\
\hline Zone 3 & Build heritage protection zone & 5 \\
\hline Zone 4 & Landscape protection zone & 23 \\
\hline Zone 5 & Regulated development zone & 6 \\
\hline & Total & 45 \\
\hline
\end{tabular}




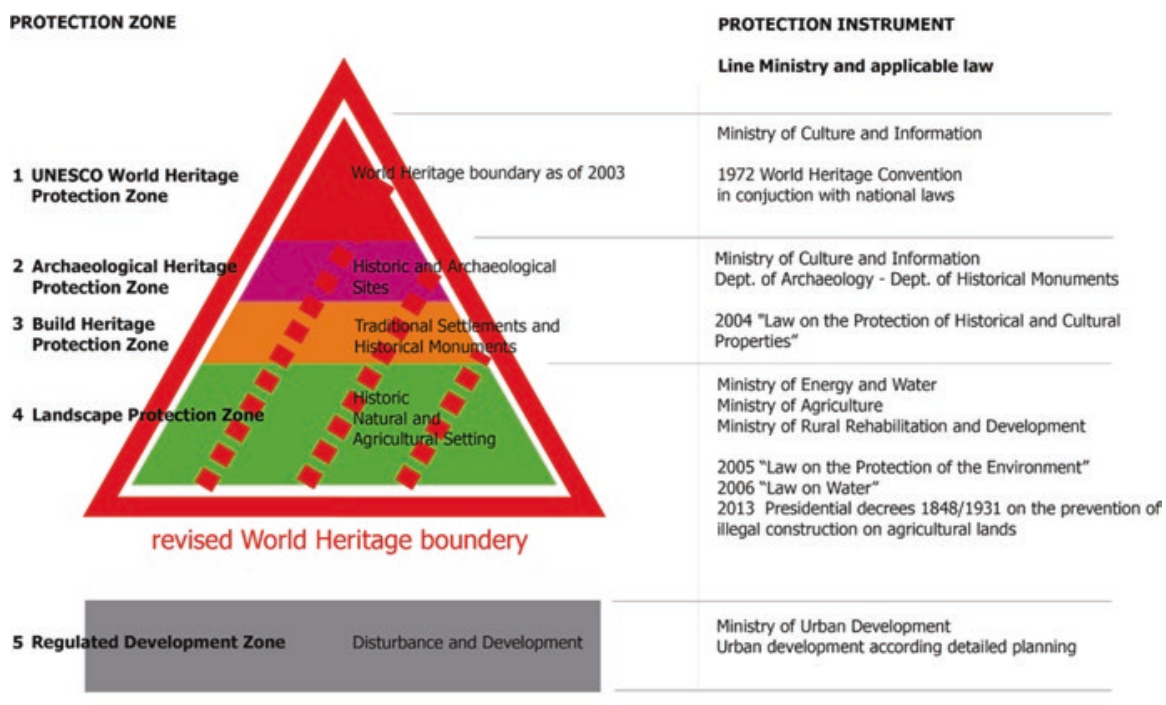

\section{sustainable development under the guidance of the Bamiyan Cultural Landscape Coordination Committee (BCLCC)}

Fig. 2 Overview scheme of the protective zoning proposal of the Cultural Master Plan (CMP) with updated law instruments as of 2016

CMP Zone 2 (Sub-surface Archaeological Heritage Protection Zone) defines the areas that have been identified to be of highest underground archaeological importance ${ }^{7}$ and covers in total around 6 square kilometers.

CMP Zone 3 (Built Heritage Protection Zone) defines the areas above ground with historically important traditional settlement structures and significant historic buildings. The National Heritage Protection zone is highly fragmented and covers presently in total five square kilometers. Zone 2 and Zone 3 fall under the jurisdiction of the 2004 Law on the Protection of Historical and Cultural Properties and is administered by the Ministry of Information and Culture.

CMP Zone 4 (Landscape Protection Zone) defines the areas of the traditional irrigation systems and rivers, the woodlands along the channels, traditional agricultural cultivation, and the overall natural setting including the pasture ranges of nearby mountains. ${ }^{8}$ Zone 4 covers a total area of around 23 square kilometers out

\footnotetext{
${ }^{7}$ The archaeological underground remains (Zone 2) may vary from $0.5 \mathrm{~m}$ to more than $4 \mathrm{~m}$ below present surface mostly due to alluvial activities and some parts spread under privately owned land. More studies are needed to better understand the underground setting of the archaeological remains. Adequate individual land use regulations for this zone may be worked out without compromising the value of the underground archaeological settings.

${ }^{8}$ It comprises the largest territory within the range of the Cultural Master Plan (Central Bamiyan Valley, Entrance of Foladi, and Kakrak Valley). The field survey revealed that the terraces and slopes above the irrigated plain have a very fragile surface that is exposed to high risk of erosion. It was proposed to establish pasture regulations to protect the sparse vegetation cover and to induce afforestation with shrubs to consolidate the surface of the soils on the long term.
} 
of which 6 square kilometers are prone to high risk of flooding. It falls under the jurisdiction of the Environmental Law, the Law of Agriculture, and the Water Law. The agricultural areas are also under the protection of the Special Presidential Decree $2013(1848 / 1931)^{9}$ which prohibits the illegal conversion of these lands for other uses.

CMP Zone 5 (Regulated Development Zone) defines the areas which have been identified as development areas as CMP Zone 1-4 phenomena are not to be found here. CMP Zone 5 includes among others the proposed expansion areas (Dasht-e Isa Khan plain). CMP Zone 5 is administered by the Ministry of Urban Development. Out of the 45 square kilometers mapped, Zone 5 (regulated development zone) represents approximately 6 square kilometers directly available for urban development and new building activities.

In summary, the CMP zones 1-4 comprise the extent of the cultural landscape of the Bamiyan Valley including all the elements that can be considered the essential cultural values. The definition of these zones followed natural and human-made topographic features (meadows, river, canals, fields, terraces) allowing thus accurate identification on the ground, an essential prerequisite for future management decisions (Fig. 3).

As a result of the enacted CMP Zone 5, the Regulated Development Zone offered the way of regulating major urban planning activities which had already begun in all identified zones (e.g., on the airfield plateau Dasht-e-Isa Khan where the Minister of Urban Development laid in 2005 the foundation stone for New Town Bamiyan and today the fast-developing administration complex is expanding).

Part of the strategy for CMP Zone 5 comprised the transfer of the airfield from Bamiyan to the Shebartu plain, some $30 \mathrm{~km}$ west of Bamiyan relieving the center of the Bamiyan Valley from air traffic stress and making the land of the current airfield

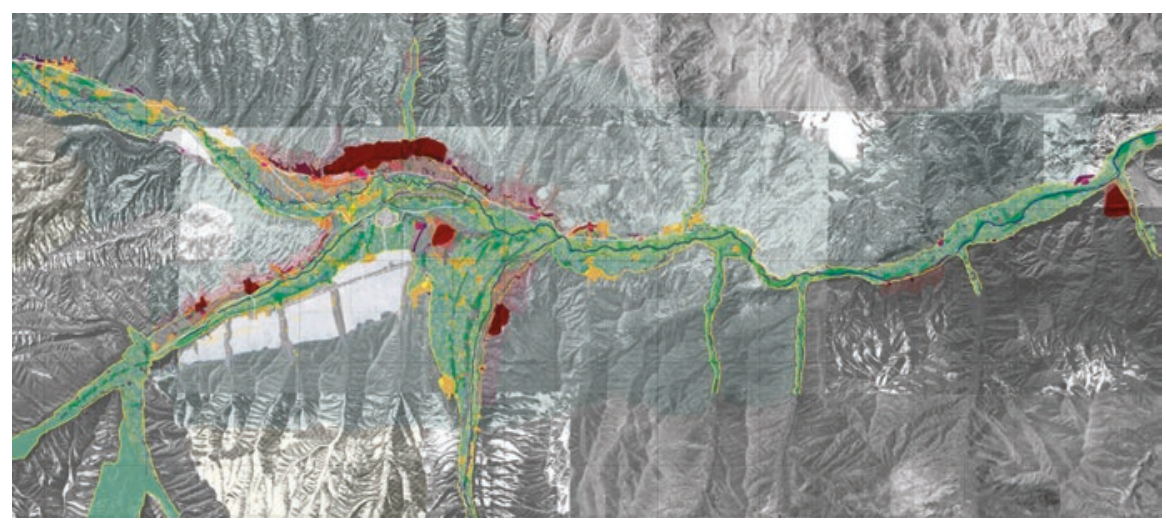

Fig. 3 Overview cultural master plan Bamiyan - colors indicate the different protection zones

\footnotetext{
${ }^{9}$ Given the Presidential degrees 1848 and 1931 (2013) about prevention of illegal constructions of residential houses on green areas, agricultural land, orchards, vineyards, and forests, officials in the center and provinces are instructed to apply the decree signed by Hamid Karzai.
} 


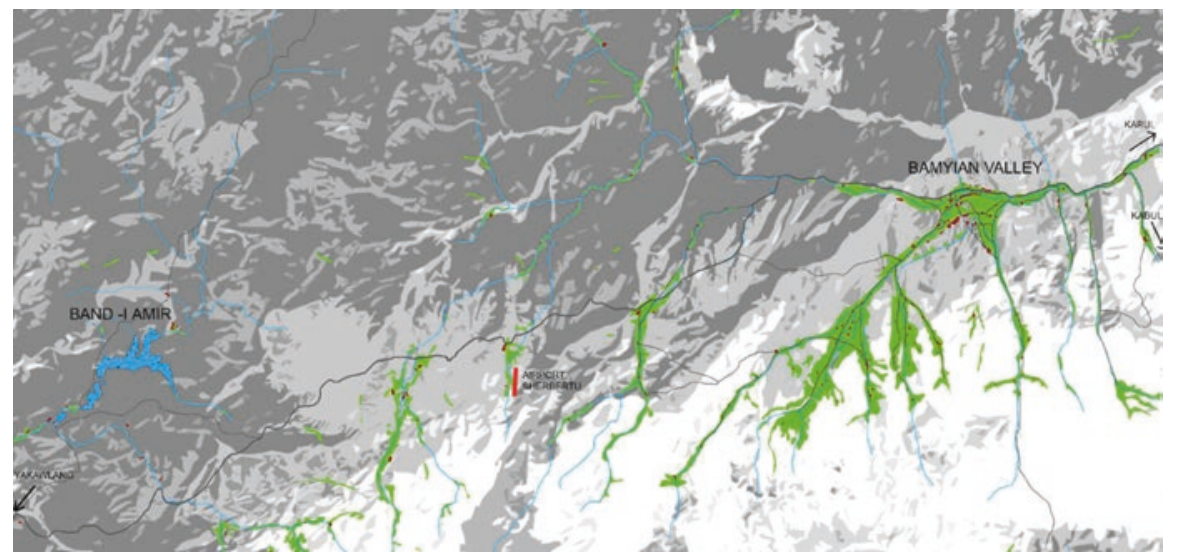

Fig. 4 Overview of the Bamiyan basin - the Shebartu airfield lies in between the central Bamiyan Valley and the Band-e Amir lakes

usable for further settlement development. On the other hand, a relocation of the airport toward the west would place such a significant infrastructure more toward the center of the province directly in between the major tourist attraction of the Bamiyan province, the Band-e Amir lakes, and the central Bamiyan Valley. Such a move would create a development stimulus for the entire Central Highland region from which many small and remote villages would profit (see Fig. 4). This part of the CMP has not yet been implemented.

With the approval of the Cultural Master Plan (CMP) in March 2006 by the Ministry of Urban Development, a useful tool had been developed to protect the cultural property of the Bamiyan Valley and to control the land use. In the same year, the Governor of Bamiyan established the Bamiyan Cultural Landscape Coordination Committee (BCLCC) as an inter-ministerial body to implement the protective zoning proposal of the Cultural Master Plan (CMP). Since then, this committee, under the chair of the Governor of Bamiyan, has been the primary agent to decide based on the CMP in critical cases upon complaints by the people.

Here the CMP functions as guiding principle and as a "overruling tool" also for all other cultural preservation activities, including the consolidation of the Buddha niches, the scientific excavations, the stabilization of plasters of the many caves around the Buddha niches and in the Foladi and Kakrak valleys and especially the activities of the Japanese team on emergency conservation of the many precious secco paintings. 


\section{The Conflicts: Cultural Master Plan, World Heritage Property, Buffer Zones, and the Urban Development}

Since the inception of the CMP, the increasing development dynamics in the Bamiyan Valley are challenging the effective implementation of a heritage management system for the World Heritage property. Consequently, Bamiyan is still listed as a World Heritage in Danger and the lack of adequate management a constant matter of concern to the World Heritage Committee. Therefore it can be said at best that the management system at present is provisional, supported through expertise from the international community to overcome the lack of appropriate administrative, scientific, and technical resources.

The management challenges have been reviewed continuously within the context of the Bamiyan Experts Working Group to which the authors have been members since its first meeting. These challenges are reflected in the various recommendations issued since (e.g., UNESCO 2006, 2011, 2013) and can be summarized as follows:

- Increase of population through repatriation of refugees from neighboring countries and arrival of more internally displaced peoples (IDPs) from within Afghanistan due to the increase of violence across the nation

- Uncertainty on the extent of the archaeological zones and especially the unidentified underground remains

- Very rigid enforcement of land use restrictions especially on agricultural lands through local authorities

- Inconsistencies in the world heritage nomination declaring Bamiyan as a cultural landscape but marking only a small portion of the landscape as belonging to the world heritage property

Out of this analysis, it has to be emphasized that the term "cultural landscape" in Bamiyan can be referenced with two connotations:

1. The Cultural Landscape declared as part of the UNESCO nomination 2003 defined as CMP Zone 1 and consisting of:

(a) The eight sub-properties themselves

(b) The areas of the eight attached buffer zones comprising approximately $5 \mathrm{~km}^{2}$ in total (see Table 1)

2. The Cultural Landscape of Bamiyan as identified in the Cultural Masterplan and defined by the $\mathrm{CMP}^{10}$ zones 1-4 of approximately $39 \mathrm{~km}^{2}$ in total (see Table 2)

As can be seen, the World Heritage property and its buffer zone (CMP Zone 1) represent only $12-13 \%$ of the total Cultural Landscape of the Bamiyan Valley (CMP zones 1-4). The CMP zones 2-4 represent substantial parts of the cultural landscape in the central Bamiyan Valley and are not included in the UNESCO nomination of

${ }^{10} \mathrm{CMP}$ Zone 5 is excluded as of no cultural significance. 
the World Heritage property. The Operational Guidelines to the World Heritage Convention request ${ }^{11}$ that the sample of cultural landscape selected "must be substantial enough to adequately represent the totality of the cultural landscape that it illustrates." Therefore, to comply with the regulations, a (partial) integration of CMP zones 2-4 into the World Heritage property should be seriously considered, but such an approach is not feasible to date since it would require a new nomination procedure.

On this background, the title of the World Heritage nomination "Cultural Landscape and Archaeological Remains of the Bamiyan Valley" can be misleading, since the cultural landscape (Reference 1) under the protection of the Convention is covering only a small fraction of the total cultural landscape (Reference 2) of the Bamiyan Valley.

The CMP as planning instrument had been officialized by a decree of the Ministry of Urban Development in 2006. However, the legal protection of the cultural landscape according to the regulations of the National Law is still awaited.

As expressed by the Governor of Bamiyan and the representatives of the BCLCC on several occasions ${ }^{12}$ the Cultural Master Plan and its detailed digital documentation proved to be a helpful planning tool. It helped in solving cases of conflict by zooming into high-resolution aerial imagery showing individual land properties in detail. However, a central problem identified by the local authorities is the matter of compensation to the farmers for restrictions imposed on agricultural land use in areas with identified underground archaeological remains and on the use of land for the construction of buildings in areas not designated for development.

With the increase of pressures resulting from the population growth also caused by the repatriation of refugees, the control over the protected cultural landscape land as identified in the CMP has become more and more difficult. As one action, the UNESCO jointly with the Government of Afghanistan increased awareness campaigns to explain the present and future importance of the World Heritage property for the people of Bamiyan at all levels of educational institutions but also in different villages involved. To better disseminate information, in 2013 a brochure in English and Farsi was produced by the UNESCO/RWTH which was distributed widely among stakeholder and institutions. Later two more workshops were held in 2016 and 2017 with the Bamiyan University, as well as consultations with local communities in villages affected by protection regulations on their lands. A significant difficulty identified is to explain the importance of an Archaeological Protection

\footnotetext{
${ }^{11}$ Operational Guidelines for the Implementation of the World Heritage Convention (2017) Annex 3 p. 81.

${ }^{12}$ The previous Governor of Bamiyan Ms. Habiba Sarabi established management coordination conferences with national and international experts in June 2012 to publicly discuss development matters from urban planning and cultural preservation point of view (see Toubekis and Jansen 2013:22-30). The current Governor of Bamiyan Mr. Mohammad Tahir Zaheer has continued this practice of holding high-level ministerial management coordination meetings in Bamiyan (Toubekis and Jansen 2017). In their statements, they repeatedly highlighted the importance of the Cultural Master Plan for the political decision-making processes in the Bamiyan Valley.
} 
Zone (Zone 2) since the underground structures as the matter of protection are not visible and therefore not readily comprehensible to the population and local authorities alike.

A critical issue put forward by village representatives is the procedure for compensation of land use restrictions on private lands that, which due to lack of funding, has not yet been financially regulated and legally formalized thus creating a significant cause of conflict and dissatisfaction.

Already in 2012, the 36th World Heritage Committee in St. Petersburg reminded that the archaeological mapping in the CMP should be more emphasized in order to avoid damage to potentially embedded archaeological remains. Their comment to establish and to "enforce building codes and regulations on development in the buffer zones of the property and other areas protected under the Afghan Law" (36 COM 7A.26) was an essential suggestion. On a practical level, this consequently calls for the revitalization of (partly destroyed) building in the traditional settlements (CMP Zone 3) but also applies for new buildings in the regulated development zone (CMP Zone 5). The height of the buildings, their outlook, form of roofing, and coloring are expected to be fitting into the traditional context.

For adequate protection of the nominated property, the regulatory framework of the CMP still requires complementary regulations such as appropriate height regulations for buildings in the central Bamiyan Valley across essential views to ensure the undisturbed visibility on the eight sub-properties and especially on the Buddha niches on the long term.

As a result of the urban growth dynamics in the central Bamiyan Valley, in 2012 the Ministry of Urban Development and Housing ordered an Afghan consultancy firm (Sayed Zia Hussaini) to prepare a master plan for the urban development of the Bamiyan valley. At the occasion of the 12th Bamiyan Expert Working Group meeting 2012 in Aachen (Germany), however, the result of this study named "Strategic Plan Bamiyan" was presented as a graphical map only without any further in-depth development studies and analyses. Many new urban development zones marked in this plan were overlaying protected zones of the CMP and thus in contradiction to the initial preservation ideas. Moreover, road infrastructure proposals in this plan were not aligned with the existing street networks. Neither RWTH Aachen University nor UNESCO was involved in the finalization of this plan, although the plan header gives reference to RWTH Aachen University and the authors of the original Cultural Master Plan. The procedure that led to the creation of this "Strategic Plan Bamiyan" also raises the question of how far the overall development strategy for the Bamiyan Valley is conceptualized and finally decided. Since this plan proposed additional vast areas for urban development situated within the cultural landscape and in parts contradicting the Cultural Master Plan without providing sound scientific data for doing, it aggravated the pressure on cultural heritage in the valley leading to increased confusion among stakeholders in Bamiyan.

Lack of coordination between donor-funded development projects and governmental oversight is a general problem all over Afghanistan. Infrastructure projects are often planned and decided centrally with little or no involvement of the local government authorities. There is a measurable dissatisfaction growing among the 
local authorities and the local population how the central government authorities handle major infrastructure projects concerning preservation efforts. On the other side, there exists a planning uncertainty at government level due to loss of crucial experienced staff to the private sector and general weak communication and collaboration attitude among different ministries at an operational level. The Cultural Master Plan as protective zoning plan was conceptualized to support infrastructure development at an early planning stage requesting the adjustment of project plans according to preservation needs within the different protection zone. The "Strategic Plan Bamiyan" conceived by some to support the management efforts for the preservation and development of Bamiyan, in contrast, raised new problems without solving existing ones. ${ }^{13}$ Therefore the implementation of this plan was halted by the new Minister of Urban Development in $2017^{14}$ in favor of further scientifically based socioeconomic studies that shall result in a new urban development plan with the aim to properly balance the interests of landscape preservation and development needs.

A significant fact to consider is that the economic basis of the Bamiyan Valley is still in its majority of rural character. The so-called Bamiyan town or city mainly consists of urban services such as trade, commerce, and production lined up along the Bazaar Street next to the Bamiyan River. Located right in the middle of the plains opposite to the main Buddha cliff, it represents the commercial center of the valley surrounded by the cultural landscape (CMP Zone 4). During the initial CMP survey in 2005, the number of shops there counted almost 900, while these numbers have reached more than 2000 after 10 years according to a statement of the local authorities.

A local initiative by the current Governor of Bamiyan and the BCLCC indicates high sensitivity toward the issues of uncontrolled business expansions in the CMP Zone 2 and CMP Zone 4. Instead, they have offered to relocate production activities in areas outside the cultural landscape. Here there is the need to update the topographical information of the CMP in an active monitor cycle to reflect these current changes in the built environment.

Due to the development dynamics in the valley in recent years, several other new urban clusters are developing rapidly in the designated Regulated Urban Development Zones as identified with the Cultural Master Plan (CMP Zone 5). These development areas are mostly located on the hill slopes of barren land and not interfering with the cultural landscape such as the areas near the airfield in the south (Dasht-e Isakhan). They can be found close to the new hospital in the west (Mullah

\footnotetext{
${ }^{13}$ These critics were also formulated in the World Heritage Committee meeting in 2016 in Istanbul (40 COM 7A.26 Nr 3) Notes with satisfaction that the Management Plan has been officially adopted and integrated into the Bamiyan City Master Plan, a tool which aims to control development pressures, but regrets that no updated report has been submitted on how these mechanisms work, especially in view of the strong development pressures observed recently;

${ }^{14}$ Personal communication of the Minister of Urban Development HE Sadat Mansoor Naderi at the occasion of a workshop in Kabul in October 2017 together with UNESCO on the planning of Bamiyan in the future (Toubekis and Jansen 2017).
} 
Ghulam), and the new town settlements of Haidarabad and Seydabad toward the Kakrak Valley in the southeast close to the newly established university campus. The general problem of these developments is that they are of an urban character in sharp contrast to the overall rural context of the valley. Besides the issue of limited lands for such urban extensions, these new areas require additional secondary infrastructures such as networks of roads, electricity, water supply, and sanitation/canalization of wastewaters. The architectural styles favored by the new town inhabitants do appear in sharp contrast to traditional building types in the Bamiyan Valley. Also, these new urban areas also have a different social structure since its inhabitants are no more farmers but have to rely on the slowly emerging non-rural economy to make their living.

Within the recent initiative of the Cities for All Programme supported by UN-Habitat, a Bamiyan City administrative boundary was defined consisting of four separate administrative sub-districts governed by the mayor and the municipality council. This initiative is part of overall urban reforms in Afghanistan, for providing better municipal services to the people (GoIRA 2014, 2015, 2016).

The marked territory of this "new" (UN-Habitat) city of Bamiyan (see Fig. 5) predominantly covers cultural landscape areas identified by the CMP zones $2-4$. The colors indicate the average "urban density" expressed as build-up area divided by a number of dwelling units. Therefore the traditional rural settlement clusters do not appear in this map due to their low-density profile well situated for the cultural landscape in contrast with the newly established urban development areas. The plan

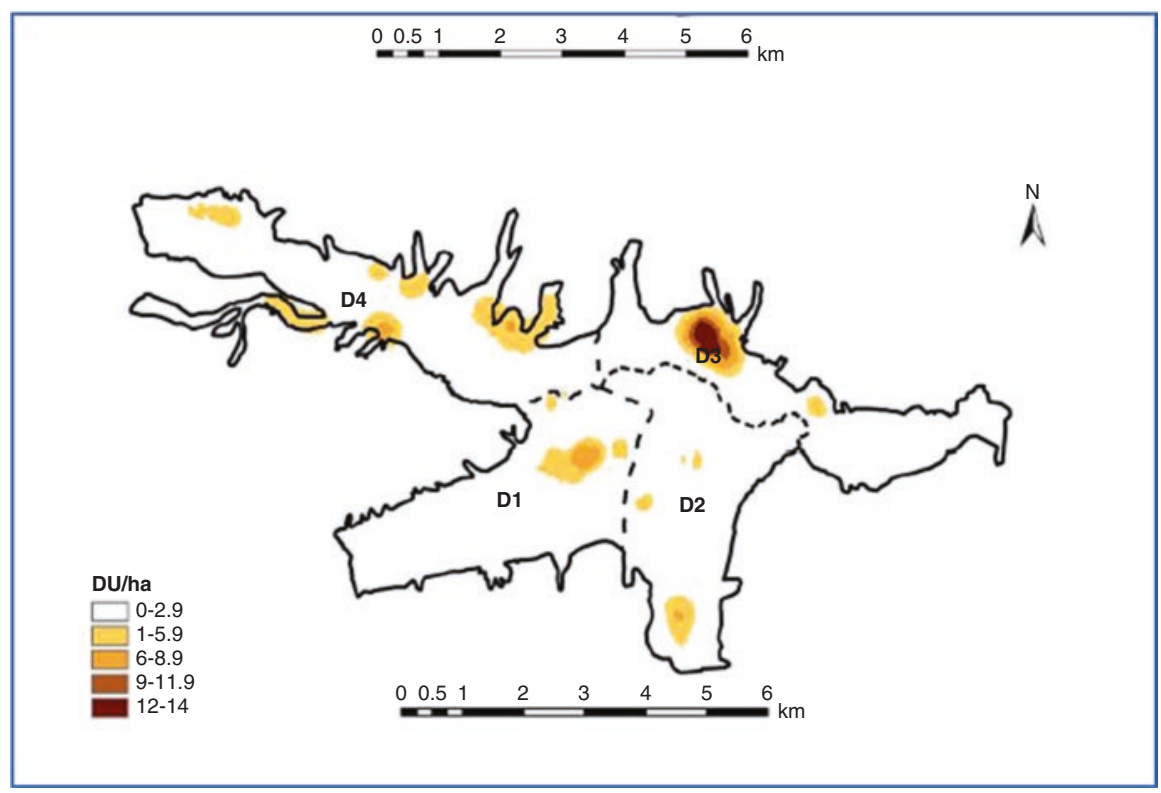

Fig. 5 The four administrative units of the city of Bamiyan with the identification of growing settlement clusters (Source: GoIRA (2015), State of Afghan Cities report 2015, Vol. 2, p.12) 
with its four districts points toward a decentralized urban model with different densely populated formal and functional clusters. District D1 already hosts the government, district D2 is marked by the university, while district D3 is primarily residential, and in district D4, a modern hospital has been built. Centralization of all these urban forms and functions would result in a devastating effect on the cultural landscape, whereas a future decentralized urban development model would coincide with the vision of the CMP. It is the challenge for the future to pursue a decentralized urban development in the Bamiyan Valley that both provide appropriate services to the people and also respect the general rural population profile. The President's proclamation 1848/1931 of 2013 to prevent illegal conversion of agricultural land for construction purpose by law is a clear sign toward keeping the economic, agrarian basis for the majority of the population.

In the long term, the development dynamics will demand more land for construction and settlement, and it goes without saying that this cannot be dealt within the limits of the small Bamiyan Valley represented in large parts by the territory of the CMP. This will result in a broader view of a "Greater" Bamiyan region, and there is the need to guide this development toward other suitable expansion areas such as the plains of Shebartu about $30 \mathrm{~km}$ west beyond the Bamiyan Valley. It is close to the second tourist attraction of Bamiyan, the Band-e-Amir lakes, and a suitable alternative for settlements with almost unlimited expansion territory. It was already proposed during the set-up phase of the CMP as a replacement alternative for the current airfield in Bamiyan combined with hotels and tourist infrastructure to develop the tourist potential more centrally in the province. This calls for a strategy that has both landscape preservation as well as balancing of development needs and challenges in mind.

\section{The Cultural Masterplan Between Conservation and Progress: The Dilemma of Sustainability}

The Cultural Master Plan enacted in 2006 has allowed the government to regulate the development in the valley encompassing regulations for landscape as well as cultural heritage preservation. Furthermore, the conception of broader landscape protection has been adopted by the new "Environment Law" of Afghanistan. The inclusion of Cultural Landscape protection into the Cultural and Antiquities Law is still awaited based on the positive experiences in Bamiyan with the Cultural Master Plan. Landscape protection has been successfully implemented at the Band-e Amir lakes (First National Park of Afghanistan in 2012) and for the mountainous regions above $3300 \mathrm{~m}$ of the Koh-e Baba Mountain range (Shah Foladi Protected Area in 2015). These nominations underline the high landscape value of this part of the Bamiyan basin and indicate the potential toward an environmentally and culturally sensitive tourism in the Bamiyan province. ${ }^{15}$

\footnotetext{
${ }^{15}$ For more details see GoIRA 2014.
} 
However, it is of the highest importance to clarify the direction of the future development of the Bamiyan Valley to build a sound strategy to achieve clear development objectives. The Cultural Master Plan can be a helpful mechanism here since it has defined already preservation objectives for the World Heritage site which have to be aligned with broader development objectives on the level of the entire Bamiyan province.

The lack of clear planning policy on a national level in the past has led to a plethora of approaches on the regional and local level in practice as a result from "ad hoc" decision-making to solve development needs. It is, therefore, essential in the future to advocate for a precise definition of development objectives and planning tools within the national planning system, with awareness on their proper naming and meaning in the different languages used.

A strategic approach, therefore, would have to encompass initiatives in three major domains:

1. Sustainable development: Definition of a vision for the Bamiyan province by the Afghan Government as a legally binding manifestation directed to the authorities and the civil society sector following the ideas set out in the Sustainable Development Goals (SDGs) of the UN Agenda 2030.

2. Hierarchy of planning tools: Definition of plans that are coherently aligned according to the different scales of planning (Regional Development Plan, Cultural Master Plan, Urban Development Plan) respecting the vision under 1.

3. The human needs have to be well respected with priority to the vision under 1 .

\subsection{The Development Vision (Legal Manifestation of the Development Objectives for the Valley)}

The nomination of the Cultural Landscape and Archaeological Remains of the Bamiyan Valley on the World Heritage List and all other legal edicts and laws, clearly expresses the determination of the Afghan Government to protect the historical and cultural setting of the central Bamiyan valley in its historic and present form. The government has continued these efforts over time despite the difficult overall general conflict situation in the country as expressed on many occasions at national and international workshops during the last years. This indicates an understanding of a general strategy for the future development of the Bamiyan Valley. This strategy shall include parameters for planning in the valley which should be based on:

(a) Keeping the primarily rural character within the CMP territory

(b) Further development of tourism opportunities in the region for the benefit of the local population

However, a coherent and comprehensive vision document for the Bamiyan province has yet not been elaborated. Such a vision document shall include a collection of the various plan documents among others the Cultural Master Plan (CMP), the relevant 
legal protective provisions (Environment Law, Culture Law) including the according edicts of the Presidential office and most notably a statement that the vision is endorsed on local, provincial, and national level by the most crucial stakeholders. Such a vision document would be a useful instrument also to streamline international aid assistance more efficiently. A legal manifestation is necessary to implement this vision, calling for an officialized declaration through the Afghan Government emphasizing the public benefits of cultural landscape protection such as introduced with the CMP with all consequences for the valley.

\subsection{Hierarchy of the Planning Tools}

The Cultural Master Plan (CMP) has been sanctioned in 2006 as a legal tool having such broader development vision in mind and was designed to be far-reaching to allow for more detailed plans on an operational level to follow later. With the scientifically proved and recorded qualities and with the legal regulations/protections, the five zonings of the CMP enable the government to control actions and to develop further integrated planning tools. An ideal planning hierarchy as conceptualized during the creation phase of the CMP is shown in Fig. 6.

The provincial development policy based on Sustainable Development Goals (SDGs) is defined in the Regional Development Plan ${ }^{16}$ (Hierarchy 1). The Regional Development Plan covers all development aspects such as health service, education, economic growth, agricultural industry, and job creation.

The plan also coordinates infrastructure programs for roads and settlements; therefore after proper analysis, it has to identify area-wise the loci for the new regional decentralized clusters (city settlements) hosting all activities for sizeable modern expansion integrating the protected area of the CMP (Hierarchy 2) into the overall provincial development policy. In the case of the center of Bamiyan, new clusters should be located outside of the Cultural Landscape in the central Bamiyan Valley close to the plains of Shebartu further to the west. It should also host the new airport, to be translocated from its present location which is blocking the Bamiyan town development area.

The stated vision of the Bamiyan Cultural Master Plan (CMP) is the preservation of the Cultural Landscape of the Bamiyan Valley in respecting rural livelihood and promoting a Culture of Peace through cultural and ecological sensitive tourism. This vision is the guiding principle for the following planning levels.

Regarding the further clustering of settlements inside the CMP territory, the new Urban Master Plan (Hierarchy 3) for the new city of Bamiyan consequently should

\footnotetext{
${ }^{16}$ The Regional Development Plan is a needs assessment document prepared by the Ministry of Urban Development Affairs (MUDA) for the purpose of budgetary allocations within the Presidential Office, especially needed for the coordination of larger infrastructure investments planned or foreseen by different ministries (personal communication with the director of planning of MUDA).
} 


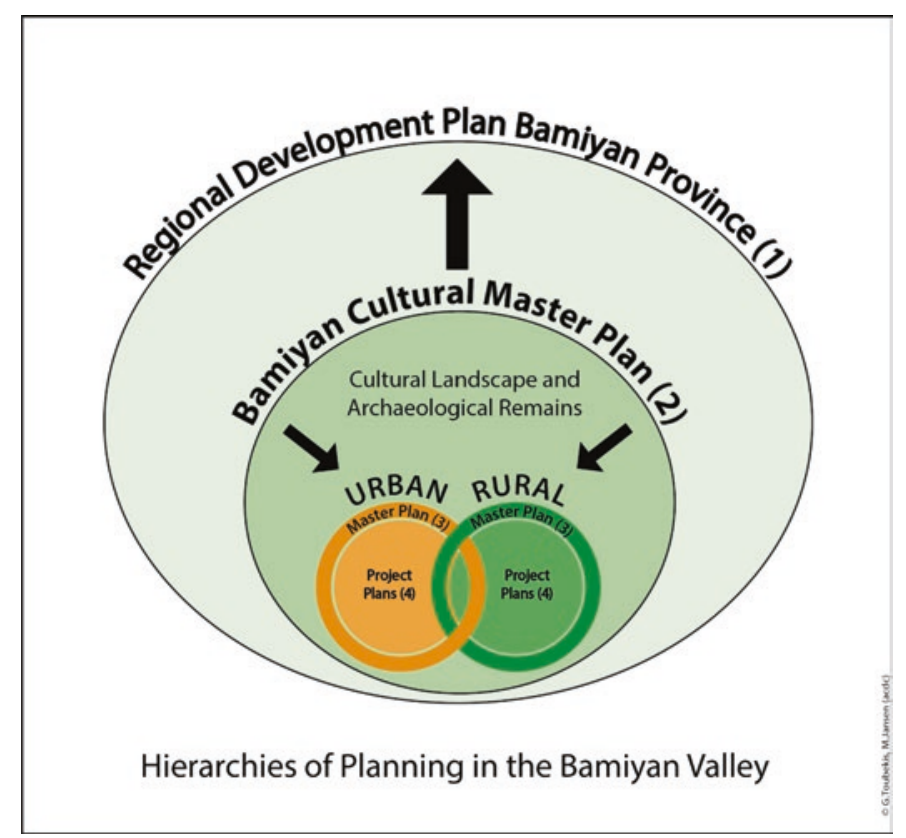

Fig. 6 The Cultural Master Plan as an intermediate level informing broader development goals and addressing local development and preservation needs (Graphic by the authors)

have to respect the regulations set out in the CMP (Hierarchy 2). The same would also account for an urgently needed Rural Master Plan (Hierarchy 3), which is not yet on the agenda, to allow for systematically improving the livelihood conditions of the rural population within the central Bamiyan Valley. Therefore individual large- and small-scale projects in the central Bamiyan Valley have to be carefully planned (Hierarchy 4) with special provision according to the individual urban areas or rural areas into which they are situated. These special provisions have to be identified within the required environmental and heritage impact assessments that are mandatory for projects within the World Heritage context.

Within these planning tools, the requested Building Regulations would deal with the appearance of constructions in CMP Zone 1, repair, rebuilding, and alteration of buildings in CMP Zone 3 and CMP Zone 4, as well as the newly erected buildings in CMP Zone 5. However, any inevitable change (land use, functions) of CMP zones 2, 3, and 4 should have to be worked out together with the CMP experts, the ministries involved and the Governor's office and, of course, with the representatives of the people of Bamiyan. For significant changes ahead of the action, feasibility studies should be conceptualized and shared with international experts and presented to the World Heritage Committee before final approval and implementation. Such a management system, if established for the Bamiyan Valley, would also help allow for the removal from the list of World Heritage List in Danger, as such provisions would ensure the proper preservation of the World Heritage property and the cultural landscape as a whole for the long term. 


\subsection{The Human Needs}

One of the primary aims of action for the Afghan Government and the international aid assistance still is the support of the local population of the valley, which is mostly dependent on a rural economy. Addressing immediate local needs of the day for the local people and their future requires a fine-grained bottom-up communitybased consultation process, while the planning strategies pursued so far on behalf of the government and to some extent from the international organizations is, in general, a top-down approach. The constraints resulting out of the World Heritage nomination and the Cultural Master Plan for some parts of the local population create restrictions on use and rights primarily related to private land property. This results in limited support and understanding for the preservation of the cultural values as defined in the World Heritage nomination and the CMP. It is most probably the highest challenge in the implementation efforts for a functioning management system for the site to achieve a broad understanding among all involved stakeholder, on the benefits of cultural landscape preservation both for the individual as well as the Bamiyan society as a whole. A direct benefit from the tourism, for example, will result from infrastructure development and job creation in tourism-related services, whereas the benefits from landscape protection are not that apparent. This accounts primarily for the "invisible" underground archaeological remains, hidden in mostly beneath private farmland, which cover almost $6 \mathrm{~km}^{2}$ of the valley. The possible threats resulting from the increase of tourism activities for agricultural resources and infrastructure has to be further studied to avoid adverse impact on the authenticity of the cultural landscape.

Therefore the Afghan Government together with the UNESCO has started a public awareness campaign in 2016 and 2017 through community-oriented workshops to inform about the cultural values of the valley that can be linked with tourism activities as an additional economic viable option for the local economy in the future. The expert recommendation toward the national authorities expressed that awareness campaigns should be further intensified, and public participation in the further planning processes should become more obligatory in the future. One idea that has already emerged out of these public discussions is the creation of an Archaeological Park in the Bamiyan Valley, integrating living religious areas (domestic shrines), archaeological remains, and open farmland part to create a better linkage between landscape and cultural heritage preservation. This idea would also better demonstrate the interdependency of the tangible and intangible values of the cultural landscape of the Bamiyan Valley but would require a government-led investment program for the required infrastructure. 


\section{Conclusion}

With the nomination of the Cultural Landscape and Archaeological Remains of the Bamiyan Valley to the UNESCO World Heritage List, a vital signal had been set against the barbarous iconoclasm and general hate against human depiction as expressed in the ideology of the Taliban but also as an encouragement toward tradition and culture of the Afghan people and especially of the people of the Bamiyan Valley. It was from the beginning envisioned as a signal of peace directed toward the people of Bamiyan but also to the world, to overcome the shock after the destruction of the Buddha figures.

During the years it has repeatedly been reported that these figures have retained their significance to the local population as part of the vernacular tradition of the valley, representing mythical legends rather than their original religious meaning as Buddhist icons, reiterating the wish by the people of Bamiyan to fill at least one of the niches again with a figure. ${ }^{17}$ These voices are an indication toward a healing process overcoming traumatic events, and it is currently internationally intensively discussed how cultural heritage can have an active role in this process (ICOMOS 2017a). The recommendation of the international community toward the Afghan authorities so far has been that the Western Buddha niche would be consolidated and left empty as a testimony to the tragic act of destruction and to investigate whether or not a partial reassembling of fragments of the Eastern Buddha could be an option for the Eastern Buddha niche. ${ }^{18}$ Whatever actions will be undertaken in future, it will result in a new monument in the true sense of the word monere (Latin) - to remember, commemorating the event of destruction of the legacy from previous times as well as an enduring and memorable example for the wish of the Bamiyan people longing for a peaceful future after the misery of war. It was entirely understandable for the Afghan Government that the local population demands the rebuilding of the Bamiyan Buddha figures in the now empty niches. Dealing with authenticity as a historical process, the connotations of meaning for the figures have changed since the Buddhist monks left the valley. For the local tradition with its own "authenticity," the two figures were locally known as "Salsal" and "Shamana," part of a love story. The demand for rebuilding the figures, therefore, should also be understood on that local background.

With the establishment of the BEWG, a highly effective instrument has been set up which up to today advises through UNESCO the Afghan Government. One of the essential outputs was the development of the Cultural Master Plan (CMP). Not only with the attractiveness of the World Heritage but also with its (present)

\footnotetext{
${ }^{17}$ The local names refer to the Big Buddha as Shamama and the Small Buddha as Salsal - as protagonists of a romantic love story; see also Afghanistan's surviving treasures The Guardian (4 March 2011) and Disputes damage hopes of rebuilding Afghanistan's Bamiyan Buddhas The Guardian (10 January 2011).

${ }^{18}$ See also the decision of the World Heritage Committee 36 COM 7A.26 and the recommendations of the 11th Bamiyan Expert Working Group Meeting held at Aachen University, Aachen, Germany (10-11 December 2012).
} 
peaceful situation and stability the Bamiyan Valley is a central focus of investment. Added the increasing population pressure, the agricultural land in the valley is in high demand for uses also other than farming. First cases of ground speculation demonstrate the danger of overlaying the local rural system soon by speculative "urban" systems. As demonstrated above, this dilemma only can be solved in a clear identification of a vision to keep the "rural" through the CMP and to invest in the further development of cultural tourism primarily. Since the establishment of the Cultural Master Plan in 2006 development has been accelerated, it is necessary to update the present "status quo" of the plan about the changed reality of the landscape. However, the central vision of the Cultural Master Plan remains as before, to improve the livelihood conditions of the people of Bamiyan through a careful cultural and ecological sensitive tourism approach in a preserved cultural landscape.

For the future development of Bamiyan, it is essential to define thus both a Rural Development Plan and an Urban Development Plan that are guided both by the leading concept of the Cultural Master Plan. The Rural Development Plan shall concentrate on the improvement of the living conditions of the population in the traditional settlements by focusing on existing needs there (access to drinking water, electricity, sanitation and waste management, access roads, storage for agricultural products). The Urban Development Plan shall concentrate to determine viable functions within the existing, emerging clusters and seeking to establish linkages between them directing the urban development into a spatial network of decentralized clusters each with its specific functional characteristics.

The vision of the Cultural Master Plan is guided by the cultural values of the valley calling for a balanced and careful development that does not consume the available land resources but maintains the landscape as it functions today. For being successful to preserve the cultural landscape for the future, it is fundamentally necessary to concentrate on the communities living in the cultural landscape, by involving them into the debate on the future of the valley since their actions and daily work determines the shaping processes of the landscape.

The Cultural Master Plan, therefore, calls for synergies with all local departments and national as well international agencies to identify projects in support of this vision and propose alternative location outside of the cultural landscape for development needs that are required but in conflict with the landscape preservation objectives.

\section{Bibliography}

Baker, P. H., \& Allchin, F. R. (1991). Shahr-i-Zohak and the history of the Bamiyan Valley, Afghanistan (BAR international series 570). Oxford: Tempus Reparatum.

Bernhardt, C., Sabrow, M., \& Saupe, A. (2017) Gebaute Geschichte. Historische Authentizität im Stadtraum. Göttingen: Wallstein

Fowler, P. (2003). World heritage cultural landscapes 1992-2002 (World Heritage cahier $\mathrm{N}^{\circ} 6$ ). Paris: UNESCO World Heritage Center. http://whc.unesco.org/en/series/6 
GoIRA. (2014). Justification for proposed: Shah Foladi Mountain landscape conservation area. Government of the Islamic Republic of Afghanistan (GoIRA), National Environmental Protection Agency (NEPA) and Ministry of Agriculture, Irrigation, and Livestock, Kabul: United Nations Environment Programme (UNEP), DOI:http://hdl.handle. net/20.500.11822/22393

GoIRA. (2015). Government of the Islamic Republic of Afghanistan. State of Afghan cities report 2015, vol. 2. Kabul: UN-Habitat. https://unhabitat.org/soac2015

GoIRA. (2016). Government of the Islamic Republic of Afghanistan, Atlas of Afghan City Regions 2016. Kabul: UN-Habitat. https://unhabitat.org/atlas-of-afghan-city-regions-2016

ICC. (2003). Recommendations of the first plenary session of the International Coordination Committee for the Safeguarding of Afghanistan's Cultural Heritage (ICC). http://whc.unesco. org/en/activities/245/

ICOMOS. (2002). Recommendations of the expert working group on the preservation of the Bamiyan Site, Munich, 21-22 November 2002, (Annex F of the Inscription dossier for the World Heritage nomination 2003). https://whc.unesco.org/uploads/nominations/208rev.pdf

ICOMOS. (2003). Advisory Body Evaluation - Bamiyan Valley (Afghanistan) No 208 rev. available online at: https://whc.unesco.org/document/152982

ICOMOS. (2005). Filling the gaps, an action plan for the future. http://whc.unesco.org/ document/102409

ICOMOS. (2008). The World Heritage List. What is OUV? Defining the Outstanding Universal Value of Cultural World Heritage Properties (Monuments and Sites Vol. 16), Berlin: Bäßler Verlag

ICOMOS. (2017a). ICOMOS guidance on post trauma recovery and reconstruction for World heritage cultural properties. http://openarchive.icomos.org/1763/

ICOMOS. (2017b). SALALAH guidelines for the management of public archaeological sites. In 19th ICOMOS general assembly, GA 2017 6-3-3 - Doctrinal texts, New Delhi, India.

Jansen, M. (Ed.). (2015). The Archaeological Park of Al-Baleed, Sultanate of Oman. Site Atlas along with selected Technical Reports 1995-2001. Muscat: Office of the Adviser to His Majesty the Sultan for Cultural Affairs.

Jansen, M., \& Toubekis, G. (2013). Cultural Master Plan Bamiyan (Afghanistan) - 2005-2013 (omnibus volume). RWTH Aachen University: Aachen Center for Documentation and Conservation (acdc).

JCICC. (2004). Japan Center for International Cooperation in conservation (JCICC), and National Research Institute for Cultural Properties Tokyo (NRICPT). In Protecting the world heritage site of Bamiyan. Key issues for the establishment of a comprehensive management plan 2004. Tokyo: NRICPT.

Lang, J. (1968). La Serie Neogene de Bamiyan (Afghanistan). Comptes Rendus de l'Académie Des Sciences, 266(26), 2383-2384.

Lang, J. (1972). Basins Intramontagneux Néogènes de l'Afghanistan Central. Revue de Géographie Physique et de Géologie Dynamique, 14(4), 415-427.

Lohmann, D. (2005). Registration of Cultural Zones and Traditional Architecture in the Bamiyan Valley - Field Report. Bamiyan Master Plan Campaign 2005. In M.Jansen, \& G.Toubekis, (Eds.), 2013, Cultural Master Plan Bamiyan (Afghanistan), RWTH Aachen University: Aachen Center for Documentation and Conservation (acdc), 67-84.

Mitchell, N., Rössler, M. \& Tricaud, P. (2009). World Heritage Cultural Landscapes. A Handbook for Conservation and Management (World Heritage cahier $\mathrm{N}^{\circ} 26$ ). Paris: UNESCO World Heritage Center, https://unesdoc.unesco.org/ark:/48223/pf0000187044.

Nakasis, A., \& Avgerinou-Kolonias S. (Eds.), 2016. Reconstructions: European perspectives. Scientific Symposium and Annual Meeting of ICOMOS European Committees. 6-7 June 2016. Athens, Greece. Athens: Propobos.

NRICPT. (2013). National Research Institute for Cultural Properties Tokyo(NRICPT), Geophysical survey of the buried cultural heritage in Bamiyan (Final reports). Tokyo: NRICPT. 
Reinecke, T. (2005). Environmental Assessment of the Bamiyan Valley in the Central Highlands of Afghanistan - Field Report. Bamiyan Master Plan Campaign 2005. In M.Jansen, \& G.Toubekis, (Eds.), 2013, Cultural Master Plan Bamiyan (Afghanistan), RWTH Aachen University: Aachen Center for Documentation and Conservation (acdc), 5-66

Roger, A. (1997). Court traité du paysage. Collection Bibliothèque des Sciences humaines. Paris: Gallimard.

Schnepel, B. (2013). Kultur "all inclusive". Identität, Tradition und Kulturerbe im Zeitalter des Massentourismus. Bielefeld: Transcript.

Tarzi, Z. (2005). Les résultants des fouilles du monastère oriental à la fin de la IIIe champagne en 2004. In L'art d'Afghanistan de la préhistoire à nos jours (pp. 98-124). Paris.

Toubekis, G., \& Jansen, M. (2013). Cultural landscape and archaeological remains of the Bamiyan Valley. Annual Progress report for the preparation of a management plan (2011-2012). RWTH Aachen University: Aachen Center for Documentation and Conservation (acdc).

Toubekis, G., \& Jansen, M. (2017). Restricted technical report, cultural master plan workshop in Kabul and Bamiyan (September 2017). Muscat: Aachen Center for Documentation and Conservation (ACDC), Research Center Indian Ocean (RIO).

UNESCO. (2003). UNESCO World Heritage Centre, Safeguarding of the Bamiyan Site, Phase I. http://whc.unesco.org/en/activities/248/

UNESCO. (2005). UNESCO World Heritage Centre, Safeguarding of the Bamiyan Site, Phase, II. http://whc.unesco.org/en/activities/249

UNESCO. (2006). Recommendations of the 5th expert working group for the preservation of the Bamiyan Valley, http://whc.unesco.org/en/events/354

UNESCO. (2008). UNESCO World Heritage Centre, Safeguarding of the Bamiyan Site, Phase, III. http://whc.unesco.org/en/activities/623

UNESCO. (2011). UNESCO World Heritage Centre. Final Report of the 8th UNESCO Expert Working Group Meeting for the Preservation of the Cultural Landscape and Archaeological Remains of the Bamiyan Valley (Afghanistan), Munich, Germany, March 2010. Paris.

UNESCO. (2012). UNESCO World Heritage Centre, Safeguarding of the Bamiyan Site, Phase IV, http://whc.unesco.org/en/activities/717

UNESCO. (2013). Recommendations of the 11th Expert Working Group Meeting for the Safeguarding of the Cultural Landscape and Archaeological remains of the Bamiyan Valley World Heritage Property, Afghanistan, Aachen University, held in Aachen, Germany (10-11 December 2012). http://whc.unesco.org/en/news/998/

UNESCO. (n.d.-a). Cultural Landscapes. http://whc.unesco.org/en/culturallandscape/

UNESCO. (n.d.-b). Documents on the World Heritage property cultural landscape and archaeological remains of the Bamiyan Valley see: http://whc.unesco.org/en/list/208/documents/

UNESCO. (n.d.-c). Guidelines for the implementation of the WH Convention. http://whc.unesco. org/en/guidelines/ 
The opinions expressed in this chapter are those of the author(s) and do not necessarily reflect the views of the UNESCO, its Board of Directors, or the countries they represent.

Open Access This chapter is licensed under the terms of the Creative Commons AttributionShareAlike 3.0 IGO License (https://creativecommons.org/licenses/by-sa/3.0/igo/), which permits use, sharing, adaptation, distribution, and reproduction in any medium or format, as long as you give appropriate credit to UNESCO, provide a link to the Creative Commons licence and indicate if changes were made. If you remix, transform, or build upon this chapter or a part thereof, you must distribute your contributions under the same licence as the original. This publication is also available at the UNESCO Open Access Repository: https://unesdoc.unesco.org/

The designations employed and the presentation of material throughout this publication do not imply the expression of any opinion whatsoever on the part of UNESCO concerning the legal status of any country, territory, city or area or of its authorities, or the delimitation of its frontiers or boundaries.

The authors are responsible for the choice and the presentation of the facts contained in this chapter and for the opinions expressed therein, which are not necessarily those of UNESCO and do not commit the Organization.

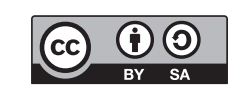

